\title{
CHARACTERIZATION AND KINETIC ADSORPTION OF THE DIFFERENT SOURCES ACTIVATED CARBON FOR LIQUID-PHASE ADSORPTION
}

\author{
Sutrisno and Yusnaidar \\ Department of Chemistry, Faculty of Education, Jambi University \\ Universitas Jambi, Kampus Pinang Masak, Mendalo Darat, Jambi, Indonesia \\ email : alyatriska@telkom.net
}

\begin{abstract}
The activated carbon from oil-palm stones of agriculural by-products from palm-oil mills in several tropical countries, a coconut shells and a solid waste exploring coals mining (ex-coal mining) were studied in this paper. The activated and characterized carbon are carried out both chemical and adsorptive properties. The different chemical activators such as $\mathrm{H}_{3} \mathrm{PO}_{4}, \mathrm{KOH}, \mathrm{H}_{2} \mathrm{SO}_{4}$ in the different ratio and also different temperature from $550^{\circ}$ to $850^{\circ} \mathrm{C}$ was done. The adsorptive properties are including the textural properties of the activated carbons are investigated. It was found that the temperature and hold time had significantly influences on the surface area and pore size in the distribution of the activated carbon. The optimum conditions for preparing these activated carbons from chars. paralyzed at $600^{\circ} \mathrm{C}$ to derive the highest specific surface areas were found to be an activation temperature of $750^{\circ} \mathrm{C}$ for phenol adsorption of $\mathrm{KOH}$ for carbon from coconut shells, $\mathrm{H}_{3} \mathrm{PO}_{4}$ for oil palm stone and ex-coal mining activator in $850^{\circ} \mathrm{C}$. For chemical characterization, AAS and a Fourier transform infrared (FTIR) spectroscopy were used to identify the inorganic components and surface organic functional groups of the activated carbons, respectively. For the determination of the adsorptive capacity of the activated carbons, adsorption of phenol was carried out using spectrophotometric analyses. Experimental results showed that phenol and iodine could be adsorbed effectively by the three different activated carbons. The adsorptive capacity of these activated carbons was comparable with those of some commercial activated carbons by using Juan, R-S et al's model ${ }^{[1]}$.
\end{abstract}

Keywords: activated carbon, oil palm stone, coconout shell, ex-coal maining, phenol reduction, kinetic adsorption, adsorptive capacity

\section{DAFTAR PUSTAKA}

1. R. S. Juang, F. C. Wu, R. L. Tseng, Characterization and use of activated carbons prepared from bagasses for liquidphase adsorption, Colloids and Surfaces A: Physicochemical and Engineering Aspects, 201(1-3): 191 - 199, (2002).

2. J. K. Brennan, T. J. Bandosz, K. T. Thomson, K. E. Gubbins, Water in porous carbons, Colloids and Surfaces A: Physicochemical and Engineering Aspects, 187-188(0): 539 - 568, (2001).

3. J. Díaz-Terán, D. M. Nevskaia, A. J. López-Peinado, A. Jerez, Porosity and adsorption properties of an activated charcoal, Colloids and Surfaces A:
Physicochemical and Engineering Aspects, 187-188(0): 167 - 175, (2001).

4. D. Mohan, S. Chander, Single component and multi-component adsorption of metal ions by activated carbons, Colloids and Surfaces A: Physicochemical and Engineering Aspects, 177(2-3): 183 - 196, (2000)

5. A. N. A. El-Hendawy, S. E. Samra, B. S. Girgis, Adsorption characteristics of activated carbons obtained from corncobs, Colloids and Surfaces A: Physicochemical and Engineering Aspects, 180(3): 209 221, (2001)

6. Sutrisno, D. W. M. Arrigan, Determination of Iron By UV-Vis Spectrophotometry after Extraction with N-Phenil N-Benzoyl Hydroxylamine, (MSc dissertation, 1997, 
The University of Salford, UK) dan dipresentasikan pada XXX Colloquium Spectroscopicum Internationale, XXX CSI 1997, Melbourne, (1997).

7. Sutrisno, Nazarudin, Development Model of Liquid Waste Treatment of Plywood and LVL Industries, International Conference on Environmental and Urban Management, Universitas Katholik Soegiya Pranata, Semarang, 2003.

8. Sutrisno, M. Rusdi, R. Adawiyyah, Efektifitas Pemakaian Koagulan dan Karbon Aktif Batubara sebagai Bahan Adsorben pada Proses Pengolahan Limbah Cair Batik, Jurnal Kimia Universitas Jambi, 4: 22 -29, (2005).

9. Sutrisno, Fifi, Development Model for Removal Total Iron in "Gambut Water" for Drinking Water, The Next Step to Nobel Prize in Chemistry, Kompetisi Penelitian Bidang Kimia untuk murid SMA, Jakarta, (2006).

10. Sutrisno, P. Sonya, Reduction of Phenol in "Gambut Water" for Drinking Water, The Next Step to Nobel Prize in Chemistry, Kompetisi Penelitian Bidang Kimia untuk murid SMA, Jakarta, (2006).

11. Sutrisno, R. Asyhar, Endang, Efektifitas Pemakaian Koagulan dan Karbon Aktif Sekam Padi sebagai Bahan Adsorben pada Proses Pengolahan Limbah Cair Batik, Jurnal Kimia Universitas Jambi, 5: 10 15, (2005).
12. Sutrisno, R. Asyhar, A. Recky, Efektifitas Pemakaian Koagulan dan Karbon Aktif Cangkang Sawit sebagai Bahan Adsorben pada Proses Pengolahan Limbah Cair Batik, Jurnal Kimia Universitas Jambi, 6: 14-19, (2005).

13. R. Asyhar, Preparation of Active Sorbent from Petroleum Coke and Its Application for Phenol and 4-Nitrophenol Reduction from Aqueuos Solution, Fresenius Environ. Bull., 3(1):149-155, (2002a).

14. R. Asyhar, dan Padliah, Studi Adsorpsi Fenol pada Arang Cangkang Kelapa Sawit (Elaeis guineensis Jacq), Laporan Penelitian, Universitas Jambi, (2005b).

15. R. Asyhar, R. Idiasari, Padliah, Melly, Studi Komparasi Daya Adsorpsi Arang Cangkang Sawit, Sekam Padi dan Batubara yang Diaktifkan dengan Aktivator Kimia, Jurnal Kimia Universitas Jambi, 4: 1- 6, (2005b).

16. A. C. Lua, J. Guo, Preparation and characterization of activated carbons from oil-palm stones for gas-phase adsorption, Colloids and Surfaces, A: Physicochemical and Engineering Aspects, 179(2-3): 151 162, (2001).

17. A. Wiener, M. Remmler, P. Kuschk, U. Stottmeister, The treatment of a deposited lignite pyrolysis wastewater by adsorption using activated carbon and activated coke, Colloids and Surfaces A: Physicochemical and Engineering Aspects, 139(1): 91-97, (1998). 
